\title{
Inter-radicular distance between the maxillary second premolar and the first molar
}

\author{
Seo-Rin Jeong ${ }^{1}$, Sun-Kyoung $\mathrm{Yu}^{2,3}$, Min-Su Kim ${ }^{1}$, and Sung-Hoon Lim ${ }^{1,3 *}$ \\ ${ }^{1}$ Department of Orthodontics, School of Dentistry, Chosun University, Gwangju 61452, Republic of Korea \\ ${ }^{2}$ Department of Oral Anatomy, School of Dentistry, Chosun University, Gwangju 61452, Republic of Korea \\ ${ }^{3}$ Oral Biology Research Institute, Chosun University, Gwangju 61452, Republic of Korea
}

(Received Feb 27, 2018; Revised version received Apr 18, 2018; Accepted Apr 24, 2018)

\begin{abstract}
The aim of this study was to evaluate the effect of the curvature of mesiobuccal root of the maxillary first molar in the space between the maxillary second premolar and the first molar, which is the preferred site for mini-implant placement. In this study, cone-beam computed tomography (CBCT) data of 85 patients (36 male, 49 female; 14-38 years old) were used to measure the mesiobuccal root length of the maxillary first molar and the distance from the cementoenamel junction (CEJ) to the most curved point of the mesiobuccal root of the maxillary first molar. The interradicular distance between the maxillary second premolar and the first molar, and the buccolingual width of alveolar bone and cortical bone thickness at the plane 4-, 6-, and 8-mm apical to the CEJ were also measured. The length of the mesiobuccal root of the maxillary first molar was $11.2 \pm 1.1 \mathrm{~mm}$, and the distance from CEJ to the most curved point was $6.4 \pm 0.7 \mathrm{~mm}$, which was about $57.4 \%$ of the root length. The interradicular distances were almost same at the 4- and 6-mm planes, but increased significantly between the 6- and 8-mm planes. Although the buccolingual widths of the alveolar bone was increased apically, cortical bone thicknesses were not different among the 4-, 6-, and 8-mm planes. The interradicular distance does not increase between the 4-mm and 6-mm planes from CEJ because of the presence of the curvature of the mesiobuccal root of maxillary first molar.
\end{abstract}

KEY WORDS: Curvature, Inter-radicular space, Maxillary first molar, Mini-implant, Tooth root

\section{서 론}

교정치료 중 미니 임플랜트는 전방부 치아의 후방이동, 개방교합의 개선, 치열의 압하 등 다양한 적응증에 이용될 수 있다[1-3]. 작은 크기, 다양한 위치에 식립 가능성, 저렴 한 비용, 비교적 쉬운 식립과 제거 등의 장점을 가지고 있 어 그 사용이 점차 증가하는 추세이다[4-6]. 미니 임플랜트 의 사용에 가장 필요한 것은 그 안정성이라고 보여지는데 Miyawaki 등은 미니 임플랜트의 안정성에 영향을 주는 요 소로 미니 임플랜트의 직경, 주변조직의 염증, 피질골의 두께 등을 들었다[7].

미니 임플랜트를 식립하기에 적절한 위치에 대한 연구 는 다양한 방법을 통해 이루어지고 있다. 사체(cadaver),

*Corresponding author: Sung-Hoon Lim

Department of Orthodontics, School of Dentistry, Chosun University, 309

Pilmun-daero, Dong-gu, Gwangju 61452, Republic of Korea

Tel.: +82-62-220-3870

E-mail: shlim@chosun.ac.kr
치근단 방사선 사진, 파노라마 방사선 사진, 컴퓨터 단층 촬영(Computed tomography), 콘빔 컴퓨터 단층촬영(Conebeam computed tomography) 등을 이용하여 피질골의 두께와 치 근 사이 거리에 대해 측정한 결과, 두꺼운 피질골의 두께 와 넓은 치근 사이 거리를 갖는 위치를 식립에 적절하다 고 추천하였다[8-15]. 서로 다른 방법을 이용한 연구에서도 공통적으로 주장하는 식립하기 안전하다고 추천되는 위치는 상악 제 2 소구치와 제 1 대구치 사이였다 $[5,8,9,11,12,14,16]$. 김 등은 콘빔 컴퓨터 단층촬영을 이용하여 상악 제 2 소구치와 제1대구치 사이에서 미니 임플랜트 식립 공간의 크기를 측정하였고, 백악법랑경계로부터 치근단측으로 올라갈수 록 달라지는 치근 사이 거리에 대해 보고하였다[12].

그러나 이러한 선행 연구들에서는 치근 사이 공간만 측 정했을 뿐 치근 사이 공간의 양상에 대한 이유는 밝혀지 지 않았고, 특히 상악 제 1 대구치의 만곡의 위치에 따라 치 근 사이 공간이 영향을 받는지에 대한 연구는 거의 없는 실정이다. 따라서 본 연구에서는 상악 제 1 대구치 근심협측 치근의 만곡이 나타나는 위치에 대해 알아보고, 더불어 근 심협측 치근의 길이 및 제 2 소구치와 제 1 대구치 사이에서 


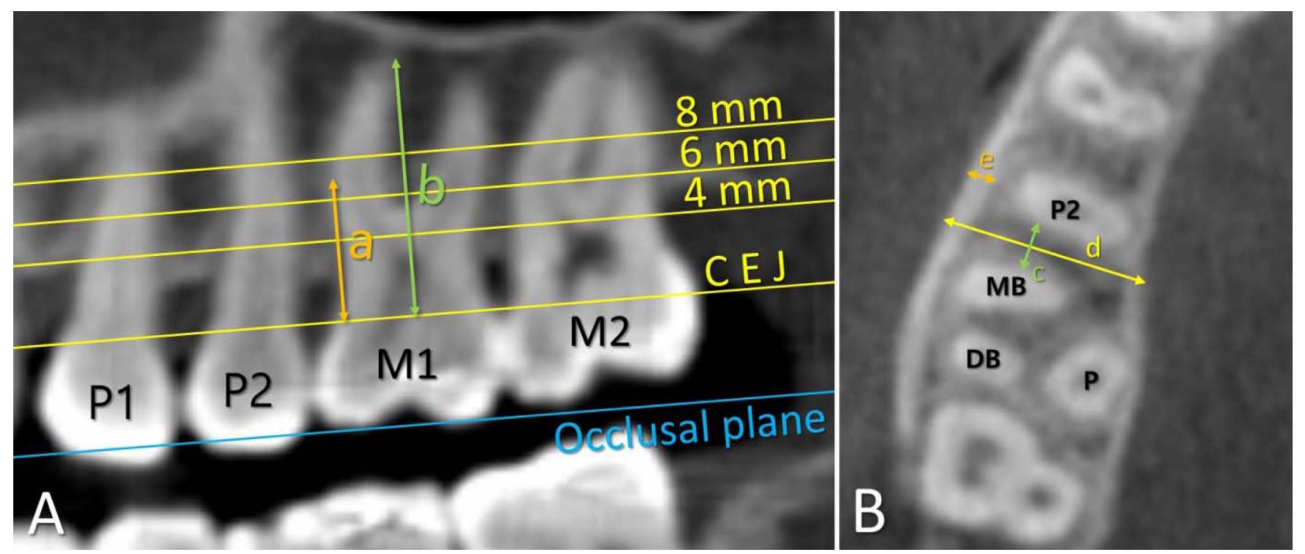

Fig. 1. Measurements items between the maxillary second premolar and the first molar: A, The occlusal plane and reference lines which were above 4, 6, $8 \mathrm{~mm}$ from cementoenamel junction (CEJ) are presented in sagittal view.; B, Each axial views were selected at the level of 4, $6,8 \mathrm{~mm}$ from CEJ; a, the distance from CEJ to the most curved point of the mesiobuccal root of the maxillary first molar.; $b$, the distance from CEJ to mesiobuccal root tip; c, interradicular distance; d, buccolingual width of alveolar bone; e, buccal cortical bone thickness; P1, first premolar; P2, second premolar; M1, first molar; M2, second molar; MB, mesiobuccal; DB, distobuccal; P, palatal.

피질골의 두께와 치조골 전체의 협설 폭경을 함께 알아봄 으로써 그 사이 관계를 알아보고자 하였다.

\section{재료 및 방법}

\section{자료수집}

이 연구는 조선대학교 치과병원 교정과에 내원하여 진 단검사를 시행한 환자를 대상으로 이루어졌다. 그 중 콘빔 컴퓨터 단층촬영을 촬영한 환자 85 명(남자 36 명, 여자 49 명; 나이 범위, 14-38세; 평균나이, 20.4세)을 무작위 추출 하였고, 두개악안면영역의 선천적 기형이 있거나, 교정치 료를 전에 받은 경력이 있는 환자, 상악중절치 또는 제1대 구치의 결손이나 수직적 위치이상 등 심각한 배열 이상이 있는 환자 등은 제외하였다.

본 연구는 조선대학교 치과병원 연구윤리위원회의 승인 을 받아 진행되었다(No. CUDHIRB 1706 002). 콘빔 컴퓨 터 단층촬영 영상은 스캐너(CB MercuRay, Hitachi, Osaka, Japan)를 통해 얻었고, 매개변수는 시야(field of view), $149.5 \times 149.5 \mathrm{~mm} ; 120 \mathrm{kV} ; 15 \mathrm{~mA}$; 스캔 시간(scan time), 9.6 seconds; 단면두께(slice thickness), $0.292 \mathrm{~mm}$; 복셀크기 (isometric voxel size), $0.292 \mathrm{~mm}$ 이었다. 계측은 OnDemand3D 1.0(Cybermed, Seoul, Korea)을 이용하였다.

\section{계측}

먼저 교합평면은 좌우 상악 중절치 절단의 중앙점과 좌 우 상악 제 1 대구치의 근심협측 교두를 지나는 평면으로 설정하였다. 교합평면에 대해 수직이고 제 2 소구치의 협측 치근과 제 1 대구치의 근심협측 치근의 중앙을 지나는 단면
으로 시상 절단 평면을 얻어 교합평면에 대해 수직으로 백악법랑경계로부터 제 1 대구치 근심협측 치근의 길이와 가장 풍융한 만곡의 위치를 측정하였다(Fig. 1A). 부착치 은의 폭경과 치근의 만곡이 나타날 수 있는 위치를 고려 하여 백악법랑경계로부터 치근단측으로 $4 \mathrm{~mm}, 6 \mathrm{~mm}, 8$ $\mathrm{mm}$ 높이의 수평 절단 평면에서 각각 제 2 소구치의 치근 과 제 1 대구치 근심협측 치근 사이의 거리, 치조골의 협설 폭경, 협측 피질골의 두께를 측정하였다(Fig. 1B). 좌우 사이에 통계적으로 유의한 차이가 없어 평균값을 사용하 였다.

\section{계측의 신뢰도}

계측은 두 명의 계측자에 의해 반복 시행되었고, 급내상 관계수로 평가하여 신뢰도 검증을 하였다. 급내상관계수 는 0.794 에서 0.968 로 믿을 만하였다. Dahlberg fomular를 이용하여 오차를 계산하였고[17], 이 값은 0.062 에서 0.407 이었다. 역시 신뢰할 만하다고 판단하였고, 두 계측자의 평균값을 이용하였다.

\section{통계학적 분석}

데이터는 소프트웨어(SPSS 20.0, IBM SPSS, Chicago, $\mathrm{IL}, \mathrm{USA}$ )를 사용하여 분석하였고, 정규성 검정을 시행하 여 협측 피질골 두께를 제외한 항목에서 정규성 분포를 따 름을 확인하였다. 협측 피질골 두께를 제외한 항목에서는 남녀 차이는 독립표본 $t$-검정, 좌우 차이는 대응 $t$-검정, 백 악법랑경계로부터 높이에 따른 세 그룹의 차이는 일원배 치분산분석을 이용하였고, 협측 피질골 두께에서는 MannWhitney $U$-검정, Kruskal-Wallis 검정을 이용하여 분석하 였다. 통계학적 유의성은 0.05 로 결정하였다. 


\section{결 과}

상악 제1대구치 근심협측 치근의 길이가 Table 1 에 나 타나있다. 평균 $11.2 \pm 1.1 \mathrm{~mm}$ 로 좌우에서는 통계적으로 유의한 차이를 보이지 않았으나 남녀 사이의 비교에서 통 계적으로 유의한 차이를 보이며 여성에서 더 짧은 경향을 보였다. 상악 제 1 대구치 근심협측 치근의 만곡의 위치는 백악법랑경계로부터 치근단 방향으로 평균 $6.4 \mathrm{~mm}$ 에서 나타났으며, 이는 치근 길이의 약 $57.4 \%$ 높이에 해당한 다. 좌우와 남녀 비교에서 통계적으로 유의한 차이는 발 견되지 않았다(Table 1).

상악 제 2 소구치의 치근과 제 1 대구치 근심협측 치근사 이의 거리는 Table 2 에 나타나 있다. 백악법랑경계로부
터 $8 \mathrm{~mm}$ 의 높이에서 가장 넓었고, 이 높이에서만 일원 배치 분산분석에서도 통계적으로 유의한 차이를 보이며 넓었다.

상악 제 2 소구치와 제 1 대구치 근심협측 치근 사이의 치조 골의 협설 폭경은 Table 3 에 나타나 있으며, 치근단측으로 갈수록 넓어지는 양상을 보이고, $4 \mathrm{~mm}$ 높이에서 통계적으 로 유의한 차이를 보이며 작았다. 남녀 비교에서는 $6,8 \mathrm{~mm}$ 높이에서 남자가 통계적으로 유의한 차이를 나타내며 큰 값을 보였다.

같은 위치에서 협측 피질골의 두께에 대한 결과가 Table 4에 나타나있다. 각각의 높이와 좌우에서 평균 $1.0 \pm 0.1 \mathrm{~mm}$ 로 거의 일정한 두께를 보이고 있으며, 통 계적으로 유의한 차이는 좌우에서도 각각의 높이에서도 나타나지 않았다.

Table 1. The length of mesiobuccal root and the distance from cementoenamal junction (CEJ) to the most curved point of the mesiobuccal root of the maxillary first molar $(\mathrm{mm})$

\begin{tabular}{|c|c|c|c|c|c|}
\hline & \multicolumn{2}{|c|}{ Male $(n=36)$} & \multicolumn{2}{|c|}{ Female $(n=49)$} & \multirow{2}{*}{$p$-value } \\
\hline & Mean & SD & Mean & SD & \\
\hline The length of mesiobuccal root & 11.5 & 1.2 & 11.0 & 1.0 & $0.032^{*}$ \\
\hline The distance from CEJ to the curvature & 6.6 & 0.8 & 6.3 & 0.7 & 0.167 \\
\hline
\end{tabular}

Curvature; the most curved point of the maxillary first molar. ${ }^{*} p<0.05$

Table 2. The interradicular distance between the maxillary second premolar and the first molar (mm)

\begin{tabular}{|c|c|c|c|c|c|c|c|}
\hline \multirow{2}{*}{ Distance from CEJ } & \multicolumn{2}{|c|}{ Male $(n=36)$} & \multicolumn{2}{|c|}{ Female $(n=49)$} & \multirow{2}{*}{$\mathrm{p}$-value } & \multicolumn{2}{|c|}{ Total } \\
\hline & Mean & SD & Mean & SD & & Mean & SD \\
\hline 4 & $3.1^{\mathrm{a}}$ & 0.6 & $2.8^{\mathrm{a}}$ & 0.6 & 0.059 & $2.9^{\mathrm{a}}$ & 0.6 \\
\hline 6 & $3.0^{\mathrm{a}}$ & 0.7 & $2.8^{\mathrm{a}}$ & 0.8 & 0.069 & $2.9^{\mathrm{a}}$ & 0.8 \\
\hline 8 & $3.4^{\mathrm{b}}$ & 0.9 & $3.2^{\mathrm{b}}$ & 1.1 & 0.424 & $3.3^{\mathrm{b}}$ & 1.0 \\
\hline
\end{tabular}

Superscript letters indicate the area with no statistically significant difference.

Table 3. The buccolingual width of the alveolar bone between the maxillary second premolar and the first molar ( $\mathrm{mm}$ )

\begin{tabular}{|c|c|c|c|c|c|c|c|}
\hline \multirow{2}{*}{ Distance from CEJ } & \multicolumn{2}{|c|}{ Male $(n=36)$} & \multicolumn{2}{|c|}{ Female $(n=49)$} & \multirow{2}{*}{$p$-value } & \multicolumn{2}{|c|}{ Total } \\
\hline & Mean & SD & Mean & SD & & Mean & SD \\
\hline 4 & $11.3^{\mathrm{a}}$ & 1.0 & $11.3^{\mathrm{a}}$ & 0.9 & 0.892 & $11.3^{\mathrm{a}}$ & 1.0 \\
\hline 6 & $12.4^{\mathrm{b}}$ & 1.1 & $11.8^{\mathrm{b}}$ & 1.0 & $0.011^{*}$ & $12.0^{\mathrm{b}}$ & 1.1 \\
\hline 8 & $12.6^{\mathrm{b}}$ & 1.3 & $12.0^{\mathrm{b}}$ & 1.4 & $0.032^{*}$ & $12.3^{\mathrm{b}}$ & 1.4 \\
\hline
\end{tabular}

Superscript letters indicate the area with no statistically significant difference. ${ }^{*} p<0.05$

Table 4. The buccal cortical bone thickness between the maxillary second premolar and the first molar (mm)

\begin{tabular}{|c|c|c|c|c|c|c|c|}
\hline \multirow{2}{*}{ Distance from CEJ } & \multicolumn{2}{|c|}{ Male $(\mathrm{n}=36)$} & \multicolumn{2}{|c|}{ Female $(\mathrm{n}=49)$} & \multirow{2}{*}{$p$-value } & \multirow{2}{*}{$\begin{array}{c}\text { Toal } \\
\text { Mean }\end{array}$} & \multirow{2}{*}{ SD } \\
\hline & Mean & SD & Mean & SD & & & \\
\hline 4 & 1.0 & 0.1 & 1.0 & 0.1 & 0.841 & 1.0 & 0.1 \\
\hline 6 & 1.0 & 0.1 & 1.0 & 0.1 & 0.758 & 1.0 & 0.1 \\
\hline 8 & 1.1 & 0.1 & 1.0 & 0.1 & 0.267 & 1.0 & 0.1 \\
\hline
\end{tabular}




\section{고 찰}

상악 제 1 대구치의 치근의 길이에 대한 연구는 거의 없 으나 세 치근의 평균은 $13.4 \mathrm{~mm}$ 로 알려져 있다[18]. 본 연 구에서 상악 제 1 대구치 근심협측 치근의 길이는 평균 $11.2 \mathrm{~mm}$ 정도로 세 치근의 평균 $13.4 \mathrm{~mm}$ 보다 작으며, 이 는 구개측 치근이 현저히 길고, 근심협측 치근의 길이가 더 짧기 때문으로 생각된다.

상악 제 1 대구치 근심협측 치근의 최대 만곡은 백악법랑 경계로부터 약 $6.4 \mathrm{~mm}$ 정도의 높이에서 관찰되며, 이는 치근 길이의 $57.4 \%$ 정도에 해당한다. 이전 연구에서 다양 한 자료를 이용한 미니 임플랜트 식립 공간에 대한 계측 연구가 있었는데, 이 중 본 연구와 같은 기준선과 같은 높 이인 백악법랑경계로부터 $4,6,8 \mathrm{~mm}$ 에서 치근 사이의 거 리를 계측한 연구들이 있었다. 허 등은 백악법랑경계로부 터 $4,6,8 \mathrm{~mm}$ 높이에서 각각 $3.2,3.5,4.2 \mathrm{~mm}$ 의 치근 사 이 거리를 보고하였고[8], 이 등은 각각 $3.2,3.6,4.0 \mathrm{~mm}$ 의 거리를 보고하였으며[16], 김 등은 $2.4,2.5,2.8 \mathrm{~mm}$ 의 거리를 보고하였다[12]. 본 연구는 $2.9,2.9,3.3 \mathrm{~mm}$ 의 결 과를 보였는데, 각각은 기준과 높이가 같은 곳에서 측정하 였으나 사체, 컴퓨터 단층촬영, 콘빔 컴퓨터 단층촬영이라 는 다른 방법을 이용하였고[8], 수평 절단 평면에서의 치 근 사이의 최소거리를 재는 기준이 달라 서로 다른 값을 보였을 것으로 보인다.

일반적으로 치근의 폭경이 치근단측으로 갈수록 감소하 는 것을 고려하였을 때, 치근단측으로 갈수록 치근 사이의 거리가 넓어지는 것을 기대할 수 있다. 그러나 콘빔 컴퓨 터 단층촬영을 이용한 본 연구와 김 등의 연구에서 $4 \mathrm{~mm}$ 높이와 $6 \mathrm{~mm}$ 높이에서 치근 사이의 거리는 통계적으로 유의한 차이가 없었다[12]. 김 등은 이에 대하여 제2소구 치와 제 1 대구치의 치근 만곡이 영향을 미쳤을 가능성에 대해 언급하였는데[12], 본 연구에서 실제로 상악 제1대구 치의 근심협측 치근의 만곡의 위치를 측정하여 보았다. 그 결과, 상악 제 1 대구치의 근심협측 치근의 만곡은 백악법랑 경계로부터 $6.4 \mathrm{~mm}$ 정도에 위치하였고, 이 영향으로 백악 법랑경계로부터 $4,6 \mathrm{~mm}$ 에서 측정한 치근 사이 거리의 증 가가 유의하게 나타나지 않는다고 할 수 있었다.

Yang 등은 콘빔 컴퓨터 단층촬영에서 백악법랑경계로부 터 $3,6,9 \mathrm{~mm}$ 의 높이에서 치조골의 협설폭경 $11.5,12.5$, $13.4 \mathrm{~mm}$ 의 결과를 보고하였다[14]. 허 등은 사체에서 백 악법랑경계로부터 $4,6,8 \mathrm{~mm}$ 높이에서 $9.8,10.7,10.8 \mathrm{~mm}$ 의 결과를 보고하였다[8]. 본 연구에서는 $4,6,8 \mathrm{~mm}$ 높이에 서 $11.3,12.0,12.3 \mathrm{~mm}$ 의 결과를 얻었는데, 이는 기존의 연구와 같이 치근단방향으로 갈수록 더 넓어지는 경향을 보였다[8,14]. 높이별로 $4 \mathrm{~mm}$ 높이에서 유의하게 작은 폭
경을 보이는 것은 허 등의 연구 결과와 일치한다[8].

Farnsworth 등은 52명의 콘빔 컴퓨터 단층촬영을 이용하 여 성인과 청소년의 피질골 두께를 비교하였다[19]. 치조 능선으로부터 $4 \mathrm{~mm}$ 높이에서 상악 제2소구치와 제1대구 치 사이에서 성인에서 $1.5 \mathrm{~mm}$ 와 청소년에서 $1.0 \mathrm{~mm}$ 의 협 측 피질골 두께를 얻었으며, 성인에서 청소년보다 두껍다고 하였다[19]. 허 등은 20 명의 상하악골의 단면에서 피질골의 두께 등을 측정하였는데 백악법랑경계로부터 $4,6,8 \mathrm{~mm}$ 높 이에서 $1.1 \mathrm{~mm}$ 의 협측 피질골의 두께를 얻었다[8]. 본 연구 에서는 백악법랑경계로부터 $4,6,8 \mathrm{~mm}$ 높이에서 일정한 $1.0 \mathrm{~mm}$ 협측 피질골의 두께를 얻었고, 이는 기존의 사체 를 이용한 연구 결과[8]와, 콘빔 컴퓨터 단층촬영을 이용 하여 청소년의 협측 피질골의 두께를 측정한 결과[19]와 거의 일치하나 미국 성인의 협측 피질골 두께를 측정한 결 과와는 차이가 있었다[19]. 이는 미국인에서 더 두껍고 한 국인에서 더 얇은 인종에 따른 차이일 것으로 보인다[15].

앞서 언급한 미니 임플랜트의 안정성에 영향을 주는 요 소 중 피질골의 두께는 높이에 따라 통계적으로 유의한 차 이가 없으므로, 제 2 소구치와 제1대구치 사이에 미니 임플 랜트 식립 시 치근 사이의 거리가 중요한 요소로 생각된 다. Schnelle 등은 치근 사이의 거리가 $3 \mathrm{~mm}$ 이상이어야 한다고 주장하였고[10], Liou 등은 미니 임플랜트는 교정 치료 동안 안정적이지 않을 수 있으며 치근 사이 식립에 있어 미니 임플랜트 직경 외에 $2 \mathrm{~mm}$ 의 여유 공간이 있어 야 한다고 주장하였다[4]. 이들의 주장에 따르면 본 연구 에서는 제 2 소구치와 제 1 대구치 사이에서 백악법랑경계로 부터 $8 \mathrm{~mm}$ 높이가 안전하다고 할 수 있겠다.

그러나 실제로 미니 임플랜트를 식립하는 데 있어서 이 높이에 식립하는 것은 어려운데, 부착치은의 폭경은 치은 변연으로부터 $3.5 \sim 5.3 \mathrm{~mm}$ 정도로 백악법랑경계로부터 2 4 mm에 해당하며 $8 \mathrm{~mm}$ 의 높이는 치조점막에 해당되 기 때문이다[12,20,21]. 미니 임플랜트 삽입 시 치조점막에 식립할 경우 조직의 염증반응의 위험인자가 될 수 있기 때 문에 [20,22] 미니 임플랜트는 주로 부착치은이나 치은치조 점막경계에 식립되고 있으며 $[10,12,20,23,24]$ 이때, 치근 손상을 방지하기 위하여 치아 장축에 대하여 기울여 식립 하는 경우 $[11,12]$ 에는 상악동의 천공 가능성을 고려해야 한다[12]. 상악동의 노출이 미니 임플랜트의 안정성에 미 치는 영향에 대한 주장은 다양하므로, 술자의 현명한 판단 이 필요한 부분이다[5,25,26].

본 연구에서는 상악에서 미니 임플랜트의 식립에 자주 이용되는 부위인 상악 제 2 소구치와 제 1 대구치 사이의 공 간에 대한 제 1 대구치 근심협측 치근의 만곡의 영향에 대 해 알아보았다. 이 공간은 제2소구치의 형태에 의해서도 영향을 받을 수 있으므로, 제2소구치의 기울기와 만곡을 포함한 형태에 대한 추가 연구를 진행하면 보다 흥미로운 
결과를 얻을 수 있을 것으로 보인다. 또한 이번 연구에서 는 상악 제 1 대구치 근심협측 치근의 만곡이 나타나는 위 치에 대해서만 연구하였기에 만곡의 정도에 대한 추가연 구가 필요할 것으로 생각된다.

\section{결 론}

상악 제 1 대구치 근심협측 치근의 길이는 $11.2 \pm 1.1 \mathrm{~mm}$ 이며, 만곡의 위치는 백악법랑경계로부터 $6.4 \pm 0.7 \mathrm{~mm}$ 높 이에 위치하고, 이는 상악 제 1 대구치 근심협측 치근 길이 의 $57.4 \%$ 정도에 해당한다. 치근 사이의 거리는 백악법랑 경계로부터 $4,6,8 \mathrm{~mm}$ 높이에서 각각 $2.9,2.9,3.3 \mathrm{~mm}$ 로, 일반적으로 치근단쪽으로 갈수록 치근 사이가 넓어질 것 이라는 예상을 빗나갔다. 즉 상악 제1대구치 근심협측 치 근의 만곡이 $6.4 \mathrm{~mm}$ 높이에 존재함에 따라, 치근 사이의 거리는 $4,6 \mathrm{~mm}$ 에서 증가하지 않고 비교적 일정하게 나 타났다.

\section{감사의 글}

This study was supported by research fund from Chosun University, 2016.

\section{Conflict of Interest}

The authors declare that they have no competing interests.

\section{ORCID}

$\begin{array}{ll}\text { Seo-Rin Jeong } & 0000-0002-8663-5941 \\ \text { Sun-Kyoung Yu } & 0000-0003-0801-1663 \\ \text { Min-Su Kim } & 0000-0001-9925-2272 \\ \text { Sung-Hoon Lim } & 0000-0003-4528-8514\end{array}$

\section{References}

1. Upadhyay M, Yadav S, Nagaraj K, Patil S. Treatment effects of mini-implants for en-masse retraction of anterior teeth in bialveolar dental protrusion patients: a randomized controlled trial. Am J Orthod Dentofacial Orthop 2008;134:18-29. doi: 10.1016/j.ajodo.2007.03.025.

2. Park YC, Lee HA, Choi NC, Kim DH. Open bite correc- tion by intrusion of posterior teeth with miniscrews. Angle Orthod 2008;78:699-710. doi: 10.2319/121806517.1.

3. Park YC, Lee SY, Kim DH, Jee SH. Intrusion of posterior teeth using mini-screw implants. Am J Orthod Dentofacial Orthop 2003;123:690-694. doi: 10.1016/S08895406(03)00047-7.

4. Liou EJ, Pai BC, Lin JC. Do miniscrews remain stationary under orthodontic forces? Am J Orthod Dentofacial Orthop 2004;126:42-47. doi: 10.1016/j.ajodo.2003.06.018.

5. Poggio PM, Incorvati C, Velo S, Carano A. "Safe zones": a guide for miniscrew positioning in the maxillary and mandibular arch. Angle Orthod 2006;76:191-197. doi: 10.1043/0003-3219(2006)076[0191:SZAGFM]2.0.CO;2.

6. Buschang PH, Carrillo R, Ozenbaugh B, Rossouw PE. 2008 survey of AAO members on miniscrew usage. J Clin Orthod 2008;42:513-518.

7. Miyawaki S, Koyama I, Inoue M, Mishima K, Sugahara T, Takano-Yamamoto T. Factors associated with the stability of titanium screws placed in the posterior region for orthodontic anchorage. Am J Orthod Dentofacial Orthop 2003;124:373-378. doi: 10.1016/S0889-5406(03) 00565-1.

8. Hu KS, Kang MK, Kim TW, Kim KH, Kim HJ. Relationships between dental roots and surrounding tissues for orthodontic miniscrew installation. Angle Orthod 2009;79:37-45. doi: 10.2319/083107-405.1.

9. Chaimanee P, Suzuki B, Suzuki EY. "Safe zones" for miniscrew implant placement in different dentoskeletal patterns. Angle Orthod 2011;81:397-403. doi: 10.2319/ 061710-111.1.

10. Schnelle MA, Beck FM, Jaynes RM, Huja SS. A radiographic evaluation of the availability of bone for placement of miniscrews. Angle Orthod 2004;74:832-837. doi: 10.1043/ 0003-3219(2004)074<0832:AREOTA >2.0.CO;2.

11. Park HS. An antomical study using CT image for the implantation of micro-implants. Korea J Orthod 2002; 32:435-441.

12. Kim SH, Yoon HG, Choi YS, Hwang EH, Kook YA, Nelson G. Evaluation of interdental space of the maxillary posterior area for orthodontic mini-implants with cone-beam computed tomography. Am J Orthod Dentofacial Orthop 2009;135:635-641. doi: 10.1016/j.ajodo. 2007.06.013.

13. Ozdemir F, Tozlu M, Germec-Cakan D. Cortical bone thickness of the alveolar process measured with conebeam computed tomography in patients with different facial types. Am J Orthod Dentofacial Orthop 2013; 143:190-196. doi: 10.1016/j.ajodo.2012.09.013.

14. Yang L, Li F, Cao M, Chen H, Wang X, Chen X. Quantitative evaluation of maxillary interradicular bone with cone-beam computed tomography for bicortical placement of orthodontic mini-implants. Am J Orthod Dento- 
facial Orthop 2015;147:725-737. doi: 10.1016/j.ajodo. 2015.02.018.

15. Ohiomoba, H, Sonis A, Yansane A, Friedland B. Quantitative evaluation of maxillary alveolar cortical bone thickness and density using computed tomography imaging. Am J Orthod Dentofacial Orthop 2017;151:82-91. doi: 10.1016/j.ajodo.2016.05.015.

16. Lee KJ, Joo E, Kim KD, Lee JS, Park YC, Yu HS. Computed tomographic analysis of tooth-bearing alveolar bone for orthodontic miniscrew placement. Am J Orthod Dentofacial Orthop 2009;135:486-494. doi: 10.1016/ j.ajodo.2007.05.019.

17. Houston WJB. The analysis of errors in orthodontic measurements. Am J Orthod Dentofacial Orthop 1983; 83:382-390.

18. Kim MS, Kim SH, Kim HJ, Kim HJ, Park BG, Park BS, Park JT, Park JC, Bae YC, Yu SK, Lee YH, Jung HS, Cho SW, Cho US, Heo GS. Dental anatomy and morphology. 3rd ed. Seoul: Daehannarae publishing; 2016. p. 179.

19. Farnsworth D, Rossouw PE, Ceen RF, Buschang PH. Cortical bone thickness at common miniscrew implant placement sites. Am J Orthod Dentofacial Orthop 2011; 139: 495-503. doi: 10.1016/j.ajodo.2009.03.057.

20. Liu H, Wu X, Yang L, Ding Y. Safe zones for miniscrews in maxillary dentition distalization assessed with cone-beam computed tomography. Am J Orthod Dento- facial Orthop 2017;151:500-506. doi: 10.1016/j.ajodo. 2016.07.021.

21. Kim JS, Moon IS, Chai JK, Cho KS. Clinical study on the width of attached gingiva the subjects with healthy gingiva, or early stage of gingivitis. J Korean Acad Periodontol 1997;27:235-248.

22. Viwattanatipa N, Thanakitcharu S, Uttraravichien A, Pitiphat W. Survival analyses of surgical miniscrews as orthodontic anchorage. Am J Orthod Dentofacial Orthop 2009;136: 29-36. doi: 10.1016/j.ajodo.2007.06.018.

23. Cha BK, Lee YH, Lee NK, Choi DS, Baek SH. Soft tissue thickness for placement of an orthodontic miniscrew using an ultrasonic device. Angle Orthod 2008;78:403408. doi: 10.2319/051607-237.1.

24. Liou EJ, Chen PH, Wang YC, Lin JCY. A computed tomographic image study on the thickness of the infrazygomatic crest of the maxilla and its clinical implications for miniscrew insertion. Am J Orthod Dentofacial Orthop 2007;131:352-356. doi: 10.1016/j.ajodo.2005.04.044.

25. Ardekian L, Oved-Peleg E, Mactei EE, Peled M. The clinical significance of sinus membrane perforation during augmentation of the maxillary sinus. J Oral Maxillofac Surg 2006;64:277-282. doi: 10.1016/j.joms.2005.10.031.

26. Kravitz ND, Kusnoto B. Risks and complications of orthodontic miniscrews. Am J Orthod Dentofacial Orthop 2007;131:S43-S51. doi: 10.1016/j.ajodo.2006.04.027. 